\title{
FERTILIZERS WITH COATED UREA IN UPLAND RICE PRODUCTION AND NITROGEN APPARENT RECOVERY
}

\author{
DOSES DE FERTILIZANTES COM UREIA REVESTIDA NA PRODUÇÃO DE ARROZ \\ DE TERRAS ALTAS E RECUPERAÇÃO APARENTE DE NITROGENNIO
}

\author{
Maria da Conceição Santana CARVALHO'; Adriano Stephan NASCENTE'; \\ Paulo César TEIXEIRA ${ }^{2}$
}

1. Pesquisador, Doutor, Embrapa Arroz e Feijão, Santo Antônio de Goiás, GO, Brasil. adriano.nascente@embrapa.br; 2. Pesquisador, Doutor, Embrapa Solos, Rio de Janeiro, RJ, Brasil

\begin{abstract}
Urea is the most used N fertilizer for upland rice, however, a great percentage of $\mathrm{N}$ loss can occur with the use of this fertilizer. The use of products that provide reduction of $\mathrm{N}$ loss for urea fertilizers can contribute to increase $\mathrm{N}$ use efficiency. The objective of this study was to determine the effect of $\mathrm{N}$ rates applied in the form of coated urea in the content and accumulation of $\mathrm{N}$ in dry biomass, apparent recovery of nitrogen and grain yield of upland rice. The experimental design was a randomized complete blocks arranged in a 4 x $3+1$ factorial scheme. The treatments consisted of four sources of $\mathrm{N}$ fertilizer [1. Common urea; 2. Polymer-coated urea for slow release of N (PCU); 3. urea with the urease inhibitor N-(n-Butyl) thiophosphoric triamide (NBPT); and 4. urea coated with copper sulfate and boric acid as urease inhibitors (UCCB)], with three fertilization rates (30, 60 and $90 \mathrm{~kg} \mathrm{ha}^{-1}$ of $\mathrm{N}$ ). In addition, we included a control treatment without $\mathrm{N}$ application. Coated urea did not provide increases in rice grain yield in relation to common urea. The increasing amount of $\mathrm{N}$ resulted in significant increases in rice grain yield (from 3217 to $5548 \mathrm{~kg} \mathrm{ha}^{-1}, 2010 / 11$, and from 3392 to $4560 \mathrm{~kg} \mathrm{ha}^{-1}, 2011 / 12$ ). The apparent nitrogen recovery rate decreased with the increase in $\mathrm{N}$ applied doses.
\end{abstract}

KEYWORDS: N fertilizer. Oryza sativa. Polymer-coated urea. Slow release fertilizers. Urease inhibitor.

\section{INTRODUCTION}

Rice is part of the diet of half the world population (LADHA; KUMAR, 2011). This cereal is mostly grown in Asia under irrigation by flooding (PRASAD, 2011). However, the reduced availability of water resources for irrigation of the crop, due to increased industrial and human consumption, has demanded the search for alternatives that enable rice cultivation with greater water saving. As an alternative, we have the cultivation of rice in the upland ecosystem, which can be sprinkle irrigated or rainfed, depending on rainwater distribution (CRUSCIOL et al., 2013; NASCENTE et al., 2013). In this ecosystem, fertilization management, mainly with $\mathrm{N}$, can provide significant increases in rice grain yield (FAGERIA, 2014).

Nitrogen is one of the most dynamic nutrients in the soil (MORO et al., 2013; NASCENTE et al., 2014). However, the low efficiency of the agronomical use of this nutrient, observed in most agricultural systems, is the result, in part, of losses associated with nitrification of $\mathrm{N}$, i.e., $\mathrm{N}$ losses by leaching and denitrification of $\mathrm{N}$ $\mathrm{NO}_{3}{ }^{-}$(NASCENTE et al., 2012; FAGERIA, 2014). The efficiency of $\mathrm{N}$ use and loss processes in the soil-plant system have not only economic consequences but also environmental ones, especially when $\mathrm{N}$ oxides are emitted into the atmosphere. Nitrous oxide $\left(\mathrm{N}_{2} \mathrm{O}\right)$ has been receiving increased attention, mainly because of its contribution to the greenhouse effect and the depletion of the ozone layer (CHIEN et al., 2009). Thus, the development of technologies that increase $\mathrm{N}$ use efficiency could help to reduce losses and contamination of water (nitrate) and the atmosphere (nitrous oxide).

In Brazil, the annual consumption of $\mathrm{N}$ fertilizers in 2013 was 3.9 million tons, and of this total 1.8 million tons $(46.15 \%)$ was urea (IPNI, 2014), which is the most used $\mathrm{N}$ fertilizer. This fertilizer has a number of advantages, such as: lower price per unit of $\mathrm{N}$; high concentration of $\mathrm{N}$, which reduces the cost of transportation and application; high solubility; lower corrosivity; compatibility with a large number of other fertilizers and pesticides; and high rate of foliar absorption (FARIA et al., 2013, 2014). However, the main disadvantage of urea is the high possibility of loss by volatilization of $\mathrm{NH}_{3}$. When applied to the soil, urea suffers enzymatic hydrolysis, thus releasing ammonia (NASCENTE et al., 2012; FAGERIA, 2014).

Various modifications have been made in fertilizers containing urea to reduce losses by volatilization and to increase their use efficiency. These modifications include the addition of acidic products (BREMNER; DOUGLAS, 1971) and the 
production of fertilizers with solubility controlled by means of resins or polymers or even elemental sulfur cover (GOULD et al., 1986; FANSURI et al., 2008; CIVARDI et al., 2011; MORO et al., 2013).

As examples of products that can be used to reduce $\mathrm{N}$ loss in the agricultural systems, we have polymer-coated urea (PCU), which provide reasonable/good control over the rate of $\mathrm{N}$ release (TRENKEL, 2010). The N-(n-Butyl) thiophosphoric triamide (NBPT) is one of the most thoroughly studied urease inhibitor (KISS; SIMIHAIAN, 2002). The organo-phosphorus compounds are structural analogues of urea and are some of the most effective inhibitors of urease activity, blocking the active site of the enzyme (WATSON et al., 1998; TRENKEL, 2010). Another product is urea coated with boric acid and copper sulfate, which provide positive effects in reducing $\mathrm{N}$ volatilization losses (FANSURI et al., 2008). The acidifying effect, the similar structural characteristics of boric acid with urea and the defensive effect of $\mathrm{B}$ and $\mathrm{Cu}$ from the soil microorganisms may deviate part of the urease activity towards boric acid, consequently decreasing $\mathrm{N}$ volatilization losses (FARIA et al., 2013).

There are still few studies in the literature that demonstrate the effects of applying fertilizer containing urea coated with polymer of slow release, urease inhibitor or coated with micronutrients for upland rice crop. We have the hypothesis that the use of coated urea allows better apparent recovery of nitrogen than the common urea.

The aim of this study was to determine the effect of $\mathrm{N}$ rates applied in the form of coated urea in the content and accumulation of $\mathrm{N}$ in dry biomass, apparent recovery of nitrogen and grain yield of upland rice.

\section{MATERIAL AND METHODS}

The field experiments were conducted for two growing seasons (2010/2011 and 2011/2012) at Capivara Farm, located in the city of Santo Antônio de Goiás, GO, Brazil. The geographical coordinates of the site are $16^{\circ} 28^{\prime} 00^{\prime \prime} \mathrm{S}, 49^{\circ} 17^{\prime} 00^{\prime \prime} \mathrm{W}$. The altitude is $823 \mathrm{~m}$. The climate is tropical savanna, considered Aw according to the Köppen's classification. There are two well-defined seasons: usually, the dry season extends from May to September (autumn/winter) and the rainy season from October to April (spring/summer). The historic average annual rainfall ranges from 1500 to 1700 $\mathrm{mm}$. The historic average annual temperature is 22.7 ${ }^{\circ} \mathrm{C}$, ranging annually from $14.2{ }^{\circ} \mathrm{C}$ to $34.8{ }^{\circ} \mathrm{C}$. Additionally, the average daily temperature and precipitation during the experiment were monitored (Figure 1).
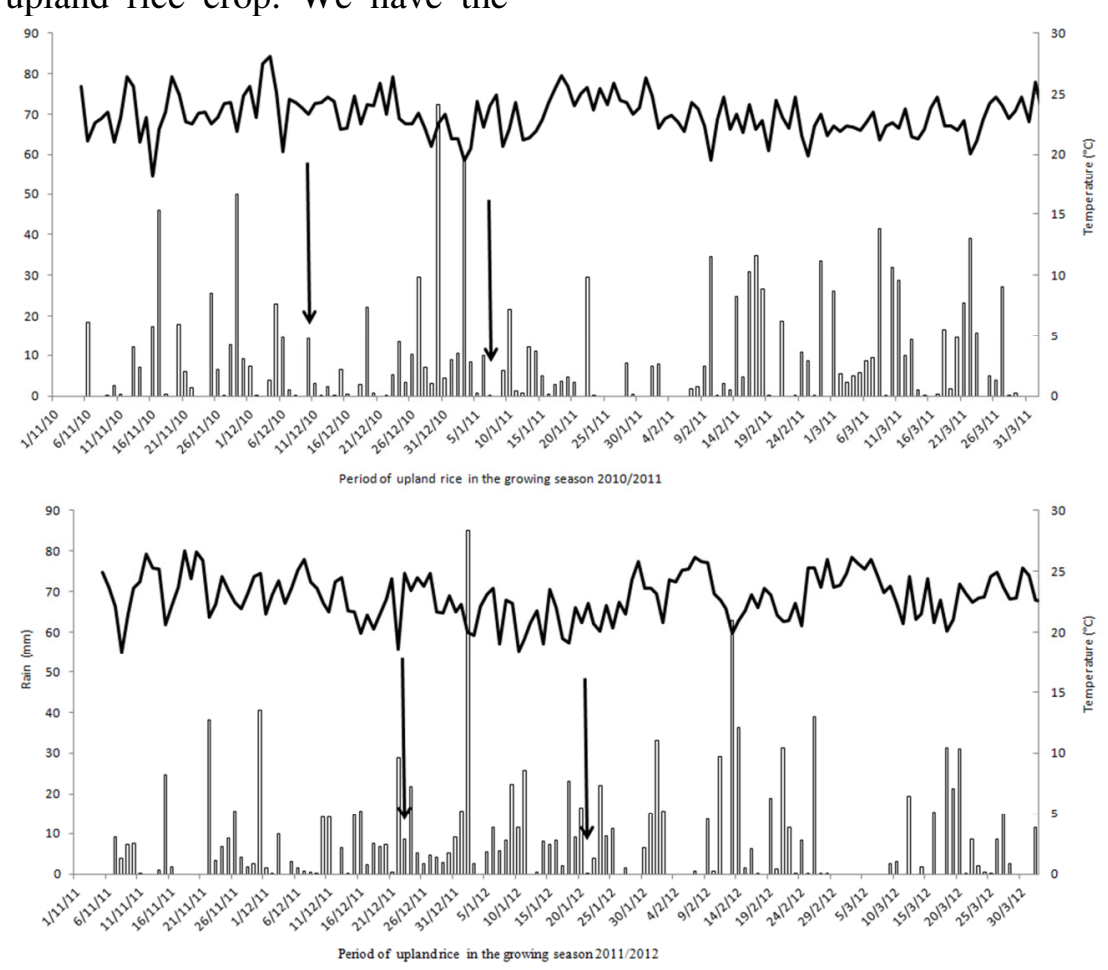

Figure 1. Temperature and rainfall in the experimental area during the trial (Nov. 2010 to Apr. 2011 and Nov. 2011 to Apr. 2012). Arrows means time that was done $\mathrm{N}$ topdressing fertilization. 
The soil was classified as a clay-textured Typic Acrustox (USDA, 1999). Prior to the experiment chemical characteristics of the soil were determined at depth of $0-0.20 \mathrm{~m}$ to characterize the soil in the experimental area. In the area $\mathrm{pH}$ was 5.9 $\left(\mathrm{CaCl}_{2}\right)$, organic matter $22 \mathrm{mg} \mathrm{dm}{ }^{-3}$, Ca $4.3 \mathrm{cmol}_{\mathrm{c}}$ $\mathrm{dm}^{-3}, \mathrm{Mg} 1.4 \mathrm{cmol}_{\mathrm{c}} \mathrm{dm}^{-3}, \mathrm{Al} 0.0 \mathrm{cmol}_{\mathrm{c}} \mathrm{dm}^{-3}, \mathrm{H}+\mathrm{Al}$ $2.4 \mathrm{cmol}_{\mathrm{c}} \mathrm{dm}^{-3}, \mathrm{~K} 169 \mathrm{mg} \mathrm{dm}^{-3}, \mathrm{P} 7 \mathrm{mg} \mathrm{dm}^{-3}, \mathrm{~S}_{-} \mathrm{SO}^{4}$ $3 \mathrm{mg} \mathrm{dm}^{-3}$, B $0.2 \mathrm{mg} \mathrm{dm}^{-3}$, Cu $1.3 \mathrm{mg} \mathrm{dm}^{-3}$, Fe 35 $\mathrm{mg} \mathrm{dm}{ }^{-3}$, Mn $62 \mathrm{mg} \mathrm{dm}^{-3}$, and $\mathrm{Zn} 3.6 \mathrm{mg} \mathrm{dm}^{-3}$. The soil analysis was performed according to Claessen (1997).

The experimental area has been cultivated in a crop-livestock no-tillage system (NTS) for seven consecutive years, which consists of following the crop rotation program with soybean (summer), followed by upland rice (summer) and the common bean (winter), followed by corn and Brachiaria (summer), followed by two years of grazing pasture. The installation of the experiments was conducted in plots in which upland rice was the crop to be grown following the crop rotation program.

The experimental design was a randomized complete blocks arranged in a $4 \times 3+1$ factorial scheme with four replications. The treatments consisted of four sources of $\mathrm{N}$ fertilizer [1. common urea; 2. Polymer-coated urea for slow release of $\mathrm{N}$ (PCU); 3. urea with the urease inhibitor N-(n-Butyl) thiophosphoric triamide (NBPT); and 4. urea coated with copper sulfate and boric acid as urease inhibitors (UCCB)] with three fertilization rates (30, 60 and $90 \mathrm{~kg} \mathrm{ha}^{-1}$ of N). In addition, we included a control treatment without $\mathrm{N}$ application. The plots consisted of 10 eight-meter-long rows, spaced 0.35 $m$ apart. The useful area of each plot was formed by the six central meters of the six central rows.

$\mathrm{N}$ application was split and $50 \%$ of the $\mathrm{N}$ rate was applied right after upland rice seedling emergence (on December $10^{\text {th }}, 2010$, and November $23^{\text {th }}, 2011$ ) and $50 \%$ at full tillering stage (on January $7^{\text {th }}, 2011$, and December $22^{\text {th }}, 2011$ ). The fertilizer was applied by hand in strips, $0.10 \mathrm{~m}$ apart from the rice rows.

Approximately 15 days before sowing, the experimental area was desiccated with glyphosate + 2,4D. The base fertilization, to be applied in the sowing furrows, was calculated according to the soil's chemical characteristics and the recommendations of Sousa and Lobato (2003). The fertilizer consisted of $17.50 \mathrm{~kg} \mathrm{ha}^{-1}$ of $\mathrm{N}$ (urea), 105 $\mathrm{kg} \mathrm{ha}^{-1}$ of $\mathrm{P}_{2} \mathrm{O}_{5}$ (triple superphosphate) and $52.5 \mathrm{~kg}$ ha $^{-1}$ of $\mathrm{K}_{2} \mathrm{O}$ (potassium chloride), and it was applied together with sowing.

The sowing was performed mechanically, using $80 \mathrm{~kg}$ of rice seeds per hectare from a mutant line 07SEQCL441 CL, which is derived from a Primavera variety and is resistant to the Imazapyr + Imazapic herbicide. The seed was sowed on December $4^{\text {th }}, 2010$, and November $17^{\text {th }}, 2011$. Before sowing, seeds were treated with Carboxin + Tiram $\left(250 \mathrm{~mL} 100 \mathrm{~kg}^{-1}\right.$ seeds $)+$ Fipronil $(100 \mathrm{~mL}$ $100 \mathrm{~kg}^{-1}$ seeds). Weed control was accomplished using Imazapyr + Imazapic herbicide at $16(100 \mathrm{~g}$ $\left.\mathrm{ha}^{-1}\right)$ and $26\left(50 \mathrm{~g} \mathrm{ha}^{-1}\right)$ days after crop emergence. Other cultural practices were performed according to the recommendations for rice crops to keep the area free of diseases and insects. Seeds emergence occurred 6 and 5 days for the first and second growing season, respectively.

Upland rice plants were sampled when they reached full flowering stage. Plants were sectioned to separate shoots from roots. The shoots were washed in water and then dried in an oven with forced air circulation at $65{ }^{\circ} \mathrm{C}$, then weighed to determine shoot dry mass content. Sub-samples of shoots were collected to determine the concentrations of $\mathrm{N}$ following the method of Malavolta et al. (1997). The $\mathrm{N}$ content was determined using the data on the shoot dry mass and nutrient concentration. Apparent recovery of nitrogen (ARN) was calculated by the formula (DOBERMANN, 2005):

$\mathrm{ARN}=[(\mathrm{UN}-\mathrm{U} 0) / \mathrm{FN}] * 100$

In which:

$\mathrm{UN}$ - total plant $\mathrm{N}$ uptake in aboveground biomass at maturity $\left(\mathrm{kg} \mathrm{ha}^{-1}\right)$ in a plot that received $\mathrm{N}$

$\mathrm{U}_{0}$ - the total $\mathrm{N}$ uptake in aboveground biomass at maturity $\left(\mathrm{kg} \mathrm{ha}^{-1}\right)$ in a plot that received no $\mathrm{N}$

$\mathrm{FN}$ - amount of (fertilizer) $\mathrm{N}$ applied $\left(\mathrm{kg} \mathrm{ha}^{-1}\right)$

Plots were evaluated concerning: number of tillering, determined by measuring plants in $1.0 \mathrm{~m}^{2}$ in the useful area of each plot at the time when the crop was at the phenological stage of pasty grains; number of panicles, determined by counting the number of panicles in $1.0 \mathrm{~m}^{2}$ in the useful area of each plot; percentage of full grains, evaluated randomly, collecting and counting the number of full grains and dividing by the total number of grains and multiplying by 100 in two samples of 100 grains from each plot; and grain yield, determined by weighing the harvested grain of each plot, corrected to $13 \%$ of water content and converted to $\mathrm{kg} \mathrm{ha}^{-1}$.

An analysis of variance and $F$ test were performed for all variables. Source and dose of fertilizer were considered fixed effects. Blocks, years and interactions were considered random effects. A comparison of means was performed with 
Tukey's test $(\mathrm{p} \leq 0.05)$ for source of fertilizer. To compare the sources with the control treatment, we used Dunnett's test at $p \leq 0.05$. Regression analysis was used for quantitative data (fertilizer doses), which we included the control treatment $(0$ of $\mathrm{N})$. Dunnett's test was performed at a significance of $p \leq$ 0.05 to compare the 0 nitrogen dose with each source of nitrogen treatment. We performed these analyses using the SAS statistical software (SAS Institute, 1999).

\section{RESULTS}

In the 2010/11 growing season, shoot dry biomass (SDB), number of tillers $\mathrm{m}^{-2}$, number of panicles $\mathrm{m}^{-2}$, percentage of full grains, grain yield, $\mathrm{N}$ concentration, $\mathrm{N}$ content and $\mathrm{N}$ apparent recovery were significantly influenced by the addition of $\mathrm{N}$ by all sources of $\mathrm{N}$ (common urea, urea polymer, urea NBPT and Urea $\mathrm{CuB}$ ), which differed from the control $(0 \mathrm{~N})$ (Table 1). However, $\mathrm{N}$ concentration had similar values for control and the $\mathrm{N}$ source Urea $\mathrm{CuB}$. Nitrogen rates affected the number of tiller, panicle density, shoot dry biomass, grain yield, $\mathrm{N}$ content in rice shoots and $\mathrm{N}$ apparent recovery. Grain yield and $\mathrm{N}$ content were higher with common urea and differed from the Urea CuB.

Table 1. Shoot dry biomass (SDB), number of tillers $\mathrm{m}^{-2}$ (NT), number of panicles $\mathrm{m}^{-2}$ (PAN), percentage of full grains (\%GRAIN), grain yield (GY), N concentration in shoots (NCONC), N content (NCONT) and $\mathrm{N}$ apparent recovery (NAR) for upland rice in relation to source of $\mathrm{N}$ fertilizer and dose in the 2010/11 growing season.

\begin{tabular}{|c|c|c|c|c|}
\hline Factors & SDB & NT & PAN & $\%$ GRAIN \\
\hline Source of $\mathrm{N}$ fertilizer & $\mathrm{kg} \mathrm{ha}^{-1}$ & number & number & $\%$ \\
\hline Urea & $4957^{+}$ & $229^{+}$ & $204^{+}$ & $73.99^{+}$ \\
\hline Urea polymer & $4858^{+}$ & $239^{+}$ & $216^{+}$ & $76.48^{+}$ \\
\hline Urea NBPT & $4750^{+}$ & $242^{+}$ & $219^{+}$ & $72.61^{+}$ \\
\hline Urea CuB & $4444^{+}$ & $235^{+}$ & $212^{+}$ & $77.71^{+}$ \\
\hline Control & 3217 & 216 & 186 & 67.82 \\
\hline Factors & \multicolumn{4}{|c|}{ ANOVA - Probability of F test } \\
\hline Source of $\mathrm{N}$ fertilizer (SNF) & 0.3099 & 0.7647 & 0.7468 & 0.4012 \\
\hline $\mathrm{N}$ rates $(\mathrm{NR})$ & $<0.001$ & 0.0354 & 0.0436 & 0.8386 \\
\hline SNF x NR & 0.0664 & 0.1003 & 0.1868 & 0.8677 \\
\hline Source of $\mathrm{N}$ fertilizer & $\begin{array}{c}\mathrm{GY} \\
\mathrm{kg} \mathrm{ha}^{-1}\end{array}$ & $\begin{array}{c}\mathrm{NCONC} \\
\mathrm{g} \mathrm{kg}^{-1}\end{array}$ & $\begin{array}{l}\text { NCONT } \\
\mathrm{kg} \mathrm{ha}^{-1}\end{array}$ & $\begin{array}{c}\text { NAR } \\
\%\end{array}$ \\
\hline Urea & $3777 \mathrm{a}^{+}$ & $18.73^{+}$ & $92.90 \mathrm{a}^{+}$ & $79^{+}$ \\
\hline Urea polymer & $3629 \mathrm{ab}^{+}$ & $18.29^{+}$ & $88.58 \mathrm{ab}^{+}$ & $68^{+}$ \\
\hline Urea NBPT & $3687 \mathrm{ab}^{+}$ & $18.42^{+}$ & $88.25 \mathrm{ab}^{+}$ & $54^{+}$ \\
\hline Urea CuB & $3181 \mathrm{~b}^{+}$ & 17.13 & $76.61 \mathrm{~b}^{+}$ & $37^{+}$ \\
\hline Control & 2329 & 17.50 & 56.48 & 0.00 \\
\hline Factors & \multicolumn{4}{|c|}{ ANOVA - Probability of F test } \\
\hline Source of $N$ fertilizer (SNF) & 0.0238 & 0.3607 & 0.0475 & 0.2750 \\
\hline $\mathrm{N}$ rates $(\mathrm{NR})$ & 0.0050 & 0.5712 & $<0.001$ & 0.0365 \\
\hline SNF x NR & 0.7136 & 0.9893 & 0.2867 & 0.4180 \\
\hline
\end{tabular}

${ }^{1}$ Means followed by the same letter do not differ by the Tukey's test for $\mathrm{p}<0.05 .{ }^{+}$means followed by this symbol differ from the control treatment (no $\mathrm{N}$ application) by the Dunnet's test for $\mathrm{p}<0.05$.

The number of tiller increased from $216 \mathrm{~m}^{-2}$ at the control treatment to 244 tiller $\mathrm{m}^{-2}$ at the $90 \mathrm{~kg}$ $\mathrm{N} \mathrm{ha}^{-1}$ (Figure 2A). Panicle density increased from 186 panicles $\mathrm{m}^{-2}$ at $0 \mathrm{~N}$ to 218 panicles $\mathrm{m}^{-2}$ at the 90 $\mathrm{kg} \mathrm{N} \mathrm{ha}{ }^{-1}$ (Figure 2B). Shoot dry mass increased from $3217 \mathrm{~kg} \mathrm{ha}^{-1}$ at control treatment to $5548 \mathrm{~kg}$ ha $^{-1}$ at $90 \mathrm{~kg} \mathrm{~N} \mathrm{ha}^{-1}$ (Figure 2C). Grain yield increased from $2449 \mathrm{~kg} \mathrm{ha}^{-1}$ at control treatment to $3887 \mathrm{~kg} \mathrm{ha}^{-1}$ at $90 \mathrm{~kg} \mathrm{~N} \mathrm{ha}^{-1}$ (Figure 2D). Nitrogen content in the rice shoots increased from $56.48 \mathrm{~kg}$ $\mathrm{ha}^{-1}$ at $0 \mathrm{~N}$ to $101.17 \mathrm{~kg} \mathrm{ha}^{-1}$ at $90 \mathrm{~kg} \mathrm{~N}^{-1}$ (Figure 2E). Nitrogen apparent recovery reduced from $77 \%$ at $30 \mathrm{~kg} \mathrm{~N}^{-1}$ to $50 \%$ at $90 \mathrm{~kg} \mathrm{~N}^{-1}$. The increase in the number of tillers, panicle density and grain yield were quadratic in nature by the application of $\mathrm{N}$ rates (Table 1). On the other hand, shoot dry biomass, $\mathrm{N}$ content in rice shoots and $\mathrm{N}$ apparent recovery fitted to linear equations. 

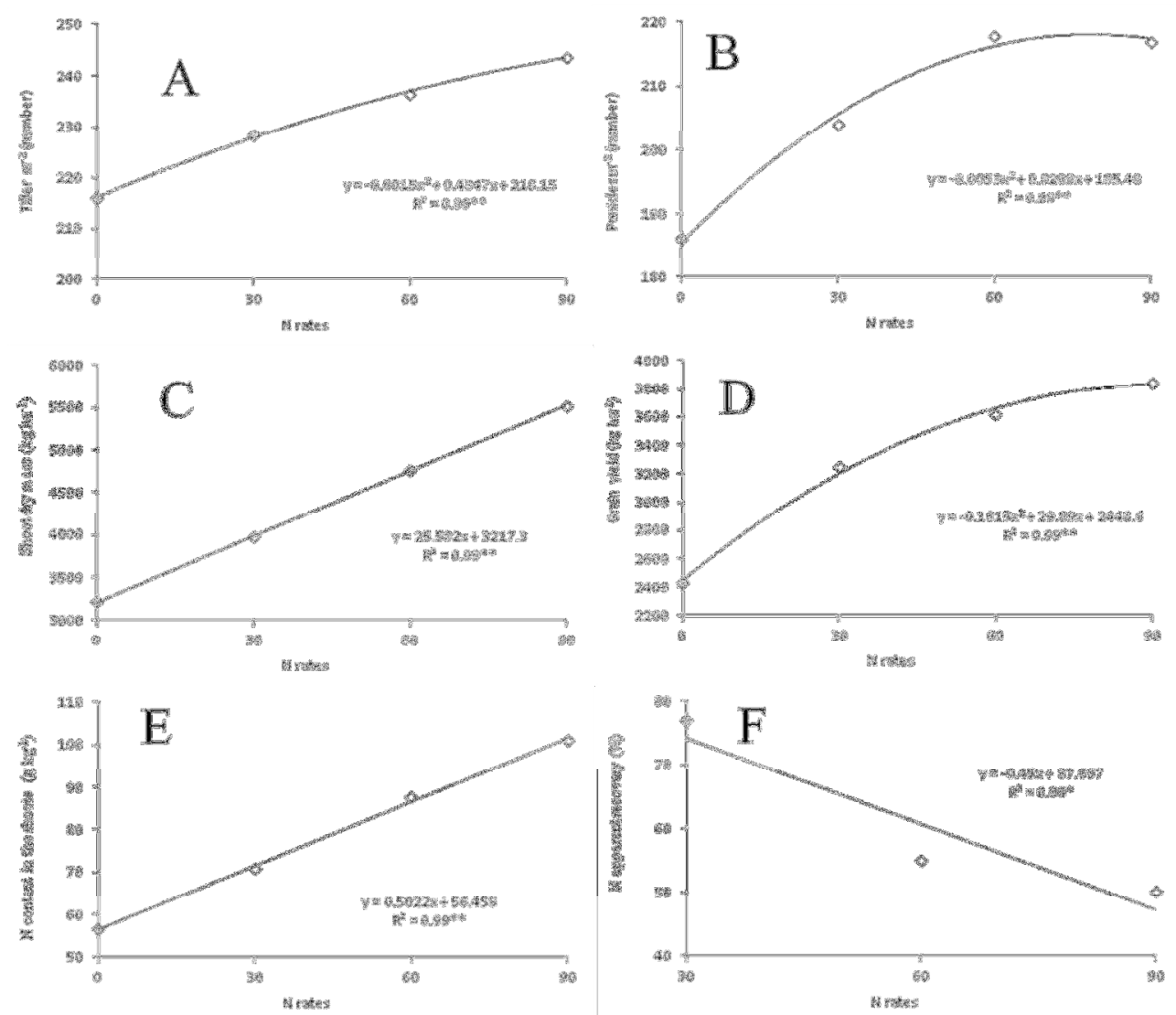

Figure 2. Number of tillers $\mathrm{m}^{-2}(\mathrm{~A})$, number of panicles $\mathrm{m}^{-2}(\mathrm{~B})$, shoot dry biomass (C), grain yield (D), $\mathrm{N}$ concentration in the shoots $(\mathrm{E})$ and $\mathrm{N}$ apparent recovery $(\mathrm{F})$ of upland rice plant as a function of $\mathrm{N}$ rates. 2010/2011 growing season.

In the 2011/12 growing season, shoot dry biomass, number of tillers, number of panicles, grain yield, $\mathrm{N}$ content and $\mathrm{N}$ apparent recovery were significantly influenced by the addition of $\mathrm{N}$ by all sources of $\mathrm{N}$ (common urea, urea polymer, urea NBPT and urea $\mathrm{CuB}$ ), which differed from the control $(0 \mathrm{~N})$ (Table 2). The number of tillers was higher with the urea NBPT source and differed from the urea $\mathrm{CuB}$ source. Common urea provided the highest values of percentage of full grains and differed from the urea polymer source.

Nitrogen rates affected shoot dry biomass, number of tillers, panicle density, percentage of full grains, grain yield, $\mathrm{N}$ content in rice shoots and $\mathrm{N}$ apparent recovery (Figure 3). Number of tillers increased from 207 tillers $\mathrm{m}^{-2}$ at the control treatment to 293 tillers $\mathrm{m}^{-2}$ at the $87 \mathrm{~kg} \mathrm{~N}^{-1}$ (Figure 3A).

Table 2. Shoot dry biomass (SDB), number of tillers $\mathrm{m}^{-2}(\mathrm{NT})$, number of panicles $\mathrm{m}^{-2}$ (PAN), percentage of full grains (\%GRAIN), grain yield (GY), $\mathrm{N}$ concentration in shoots (NCONC), $\mathrm{N}$ content (NCONT) and $\mathrm{N}$ use efficiency (NUE) for upland rice in relation to source of $\mathrm{N}$ fertilizer and dose in the 2011/12 growing season.

\begin{tabular}{lcccc}
\hline \multicolumn{1}{c}{ Factors } & SDB & NT & PAN & \%GRAIN \\
\hline Source of N fertilizer & $\mathrm{kg} \mathrm{ha}^{-1}$ & number & number & $\%$ \\
Urea & $6333^{+}$ & $265 \mathrm{ab}$ & $255^{+}$ & $76.59 \mathrm{a}$ \\
Urea polymer & $6288^{+}$ & $294 \mathrm{ab}^{+}$ & $272^{+}$ & $68.59 \mathrm{~b}$ \\
Urea NBPT & $6598^{+}$ & $314 \mathrm{a}^{+}$ & $282^{+}$ & $71.66 \mathrm{ab}$ \\
Urea CuB & $6125^{+}$ & $250 \mathrm{~b}^{+}$ & $245^{+}$ & $74.43 \mathrm{ab}$ \\
\hline Control & 3858 & 207 & 199 & 72.00 \\
\hline Factors & \multicolumn{4}{c}{ ANOVA - Probability of F test } \\
Source of N fertilizer (SNF) & 0.6189 & 0.0275 & 0.0768 & 0.0177 \\
N rates (NR) & 0.0416 & 0.0354 & 0.0138 & 0.0065 \\
SNF x NR & 0.7104 & 0.4873 & 0.1020 & 0.0736 \\
\hline
\end{tabular}




\begin{tabular}{lcccc} 
Source of N fertilizer & $\begin{array}{c}\text { GY } \\
\mathrm{kg} \mathrm{ha}^{-1}\end{array}$ & $\begin{array}{c}\text { NCONC } \\
\mathrm{g} \mathrm{kg}^{-1}\end{array}$ & $\begin{array}{c}\text { NCONT } \\
\mathrm{kg} \mathrm{ha}^{-1}\end{array}$ & NAR \\
Urea & $4335^{+}$ & 15.62 & $98.97^{+}$ & $77^{+}$ \\
Urea polymer & $4414^{+}$ & 16.80 & $104.19^{+}$ & $88^{+}$ \\
Urea NBPT & $4195^{+}$ & 16.44 & $108.21^{+}$ & $91^{+}$ \\
Urea CuB & $4355^{+}$ & 16.12 & $98.18^{+}$ & $77^{+}$ \\
\hline Control & 3392 & 15.14 & 58.64 & 0 \\
\hline Factors & \multicolumn{4}{c}{ ANOVA - Probability of F test } \\
Source of N fertilizer (SNF) & 0.7832 & 0.0927 & 0.6154 & 0.5858 \\
N rates (NR) & 0.0428 & 0.5102 & 0.0089 & 0.0009 \\
SNF x NR & 0.4436 & 0.6922 & 0.2378 & 0.3436
\end{tabular}

${ }^{1}$ Means followed by the same letter do not differ by the Tukey's test for $\mathrm{p}<0.05 .{ }^{+}$means followed by this symbol differ from the control treatment (no $\mathrm{N}$ application) by the Dunnet's test for $\mathrm{p}<0.05$.

Panicle density increased from 199 panicles $\mathrm{m}^{-2}$ at $0 \mathrm{~N}$ to 273 panicles $\mathrm{m}^{-2}$ at the $81 \mathrm{~kg} \mathrm{~N} \mathrm{ha}^{-1}$ (Figure 3B). Percentage of full grains ranged from $69 \%$ at $90 \mathrm{~kg} \mathrm{~N} \mathrm{ha}^{-1}$ to $76 \%$ at $30 \mathrm{~kg} \mathrm{~N} \mathrm{ha}^{-1}$ (Figure 3C). Shoot dry biomass increased from $3921 \mathrm{~kg} \mathrm{ha}^{-}$ ${ }^{1}$ at control treatment to $6749 \mathrm{~kg} \mathrm{ha}^{-1}$ at $76 \mathrm{~kg} \mathrm{~N}^{-}$ ${ }^{1}$ (Figure 3D). Grain yield increased from $3390 \mathrm{~kg}$ $\mathrm{ha}^{-1}$ at control treatment to $4560 \mathrm{~kg} \mathrm{ha}^{-1}$ at $84 \mathrm{~kg} \mathrm{~N}$ $\mathrm{ha}^{-1}$ (Figure 3E). Nitrogen content in the rice shoots
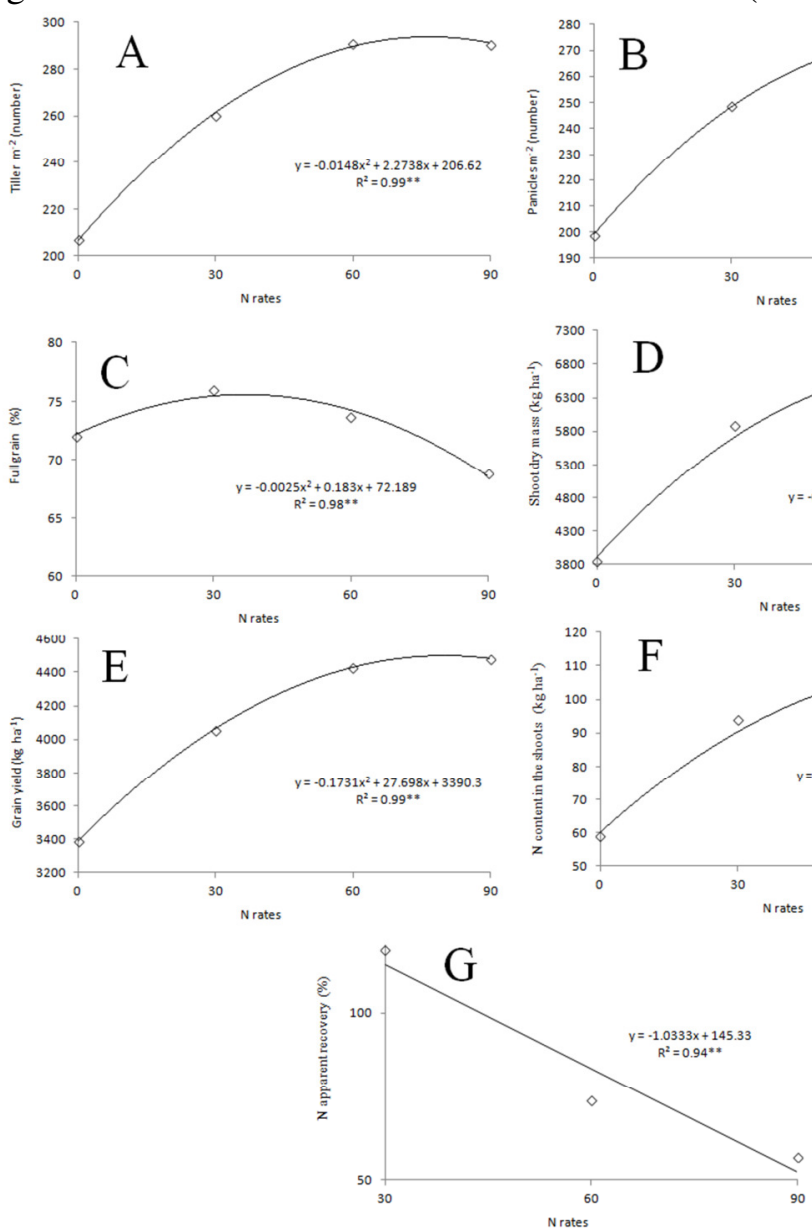

Figure 3. Number of tillers $\mathrm{m}^{-2}(\mathrm{~A})$, number of panicles $\mathrm{m}^{-2}(\mathrm{~B})$, percentage of full grains (C), shoot dry biomass (D), grain yield (E), $\mathrm{N}$ content in the shoots $(\mathrm{F})$ and $\mathrm{N}$ apparent recovery $(\mathrm{G})$ of upland rice plant as a function of $\mathrm{N}$ rates. 2011/2012 growing season. 


\section{DISCUSSION}

In the experiments conducted in the years 2010/11 and 2011/12, the use of common urea did not provide lower values for the studied variables than other sources of nitrogen. By contrast, in the 2010/11 growing season, grain yield and $\mathrm{N}$ content in rice plants from treatment with common urea resulted in high values that differed from the $\mathrm{CuB}$ urea source. This fact shows that the coated urea sources behave similarly to common urea. Related results were obtained by Fageria and Carvalho (2014) with the rice crop, Prando et al. (2013, 2012a, 2012b) working with wheat, and Silva et al. (2012) with maize. Thus, it appears that under the conditions of this study, the changes made in urea, which aimed at increasing their efficiency, were not effective in providing higher rice grain yields in the two years evaluated, since the common urea yielded similar results to the other sources.

A possible explanation for this lack of results was the rains that occurred shortly after the application of the nitrogen fertilizers (Figure 1). In the 2010/11 growing season, after the first nitrogen fertilization, at the same day, it rained $14.1 \mathrm{~mm}$, and more $3.2 \mathrm{~mm}$ in the other day. Two days after the second nitrogen fertilization, it rained $6.2 \mathrm{~mm}$ and 21.6 after fertilization. In the 2011/12 growing season, soon after the first nitrogen fertilization, at the same day, it rained $8.6 \mathrm{~mm}$ and in the next day it rained more $21.8 \mathrm{~mm}$. In the day after the second nitrogen fertilization, it rained $3.8 \mathrm{~mm}$, and $22 \mathrm{~mm}$ two days after the fertilization. This rain condition up to three days after nitrogen fertilization with urea is considered ideal to obtain better efficiency of $\mathrm{N}$ applied at topdressing, since $\mathrm{N}$ losses are minimal (Prando et al., 2013; Fageria, 2014) regardless of the source or form of the nitrogen fertilizer. Thus, for the conditions of our study (i.e., rain incorporating urea), the choice of what source of $\mathrm{N}$ would be used will depend of the price. In this case, common urea is advantageous over the other nitrogenous fertilizers tested. Likewise, Fageria and Carvalho (2014) found no differences in rice when using common urea and urea coated with polymer.

The use of increasing nitrogen doses affected most variables providing increases in the shoot dry biomass, tiller number, panicle number, grain yield and $\mathrm{N}$ content in rice leaves. Similarly, Fageria (2009), Fageria et al. (2010) and Fageria et al. (2011a; 2011b) also reported increased production of grain yield and yield components of upland rice by applying $\mathrm{N}$ in Brazilian Oxisols. Nitrogen is an important nutrient in crop development, and the use of nitrogen fertilizer in rice is directly related to increased crop productivity (FAGERIA et al., 2011b; FAGERIA, 2014).

Regarding apparent recovery of $\mathrm{N}$, we found that with increasing $\mathrm{N}$ rates, reduction of nutrient recovery rate has occurred (Figures $2 \mathrm{~F}$ and 3G). Corroborating these results, Viana et al. (2011) also reported a reduction in nutrient utilization with increasing doses of $\mathrm{N}$. This happened because the increase of $\mathrm{N}$ by fertilization could increase $\mathrm{N}$ loss and reduces its efficiency. Lara-Cabezas (2011) added that nitrogen use efficiency by crops is affected by several factors, and the recovered nutrient can be used for the following crop.

Based on our results, it appears that the application of $\mathrm{N}$ increases crop yield. However, the sources of this nutrient do not affect upland rice grain when rains occur soon after application of urea fertilizer. Prando et al. (2013) reported that when it occurred nine days without rainfall after application of various sources of coated urea, compared to the common urea, a difference among the $\mathrm{N}$ sources regarding $\mathrm{N}$ loss was observed. It occurred because of hydrolysis of urea on the surface and hence loss by $\mathrm{NH}_{3}$ volatilization. Even so, the authors observed no differences in grain yield, probably because this urea $\mathrm{N}$ loss by volatilization was not sufficient to result in differences in performance of wheat. Thus, for these authors, the use of coated urea appears feasible only in places with risk of dry spells greater than nine days after the completion of nitrogen topdressing.

\section{CONCLUSIONS}

Coated urea did not provide increases in rice grain yield in relation to common urea;

The increasing amount of $\mathrm{N}$ applied resulted in significant increases in the upland rice grain yield;

Apparent $\mathrm{N}$ recovery rate decreased with the increase in $\mathrm{N}$ applied doses.

RESUMO: A ureia é o fertilizante nitrogenado mais utilizado para o arroz de terras altas, no entanto, esse fertilizante tem grande percentual de perda de $\mathrm{N}$. O uso de produtos que proporcionam redução da perda de $\mathrm{N}$ em fertilizantes com ureia pode contribuir para aumentar a eficiência de uso do nitrogênio. O objetivo deste estudo foi determinar o efeito de doses de $\mathrm{N}$ aplicadas na forma de ureia encapsulada no teor e acúmulo de $\mathrm{N}$ na biomassa seca, recuperação aparente de nitrogênio e produtividade de grãos de arroz de terras altas. O delineamento experimental foi em 
blocos ao acaso no esquema fatorial 4 × $3+1$. Os tratamentos consistiram de quatro fontes de $\mathrm{N}$ fertilizante [1. ureia tradicional; 2. Polímero de ureia revestida para liberação lenta de N (PCU); 3. ureia com o inibidor de urease N- (n-butil) triamida tiofosfórico (NBPT); e 4. ureia revestida com sulfato de cobre e ácido bórico como inibidores de urease (UCCB)], com três doses de fertilizante (30, 60 e $90 \mathrm{~kg} \mathrm{ha}^{-1}$ de N). Além disso, incluímos uma testemunha sem aplicação de N. Ureia revestida não forneceu aumentos no rendimento de grãos de arroz em relação à ureia comum. $\mathrm{O}$ aumento da quantidade de $\mathrm{N}$ resultou em aumentos significativos no rendimento de grãos de arroz (de 3217 para $5548 \mathrm{~kg} \mathrm{ha}^{-1}$, 2010/11, e de 3392 para $4560 \mathrm{~kg} \mathrm{ha}^{-1}, 2011 / 12$ ). A taxa de recuperação aparente de nitrogênio diminuiu com o aumento das doses aplicadas de N.

PALAVRAS-CHAVE: Fertilizantes N. Oryza sativa. Polímero revestido de ureia. Fertilizantes de liberação lenta. Inibidor de urease.

\section{REFERENCES}

BREMNER, J. M.; DOUGLAS, L. A. Inhibition of urease activity in soils. Soil Biology and Biochemistry, Amsterdam, v. 3, p. 297-307, 1971. http://dx.doi.org/10.1016/0038-0717(71)90039-3

CHIEN, S. H.; PROCHNOW, L. I.; CANTARELLA, H. Recent developments of fertilizer production and use to improve nutrient efficiency and minimize environmental impacts. Advances in Agronomy, San Diego, v. 102, p. 261-316, 2009. http://dx.doi.org/10.1016/s0065-2113(09)01008-6

CIVARDI, E. A.; SILVEIRA NETO, A. N.; RAGAGNIN, V. A.; GODOY, E. R.; BROD, E. Slow-release urea applied to surface and regular urea incorporated to soil on maize yield. Pesquisa Agropecuária Tropical, Goiânia, v. 41, p. 52-59, 2011.

Claessen, M. E. C. Manual de Métodos de Análise de Solos, 2. ed. Rio de Janeiro: Embrapa Solos, 1997. $212 \mathrm{p}$.

CRUSCIOL, C. A. C., SORATTO, R. P.; NASCENTE, A. S.; ARF, O. Root distribution, nutrient uptake, and yield of two upland rice cultivars under two water regimes. Agronomy Journal, Madison, v. 105, p. 237-247, 2013. http://dx.doi.org/10.2134/agronj2012.0298

DOBERMANN, A. R. Nitrogen Use Efficiency - State of the Art. Lincoln: University of Nebraska, 2005. 16p.

FAGERIA, N. K. Nitrogen management in crop production. Boca Raton: CRC Press, 2014. 399 p. http://dx.doi.org/10.1201/b17101

FAGERIA, N. K. The Use of Nutrients in Crop Plants. Boca Raton: CRC Press, 2009. 419 p.

FAGERIA, N. K.; MOREIRA, A.; COELHO, A. M. Yield and yield components of upland rice as influenced by nitrogen sources. Journal of Plant Nutrition, New York, v. 34, p. 361-370, 2011 b.

http://dx.doi.org/10.1080/01904167.2011.536878

FAGERIA, N. K.; MORAIS, O. P.; SANTOS, A. B. Nitrogen use efficiency in upland rice genotypes. Journal of Plant Nutrition, v. 33, p. 1696-1711, 2010. http://dx.doi.org/10.1080/01904167.2010.496892

FAGERIA, N. K.; BALIGAR, V. C.; JONES, C. A. Growth and mineral nutrition of field crops. 3. ed. Boca Raton: CRC Press, 2011a. 586 p.

FAGERIA, N. K.; CARVALHO, M. C. S. Comparison of conventional and polymer-coated urea as nitrogen sources for lowland rice production. Journal of Plant Nutrition, New York, v. 37, p. 1358-1371, 2014. http://dx.doi.org/10.1080/01904167.2014.888736 
FANSURI, H.; PRITCHARD, D.; ZHANG, D. Manufacture of Low-grade zeolites from fly ash for fertilizer applications. Curtin: Curtin University of Technology, Australia, Cooperative Research Center for Coal in Sustainable Development, 2008. 98 p. (Research Report n. 91).

FARIA, L. A.; NASCIMENTO, C. A. C.; VITTI, G. C.; LUZ, P. H. C., GUEDES, E. M. S. Loss of ammonia from nitrogen fertilizers applied to maize and soybean straw. Revista Brasileira de Ciência do Solo, Viçosa, v. 37, p. 969-975, 2013.

FARIA, L. A.; NASCIMENTO, C. A. C.; VENTURA, B. P.; FLORIM, G. P. LUZ, P. H. C. VITTI, G. C. Hygroscopicity and ammonia volatilization losses from nitrogen sources in coated urea. Revista Brasileira de Ciência do Solo, Viçosa, v. 38, p. 942-948, 2014.

GOULD, W. D.; HAGEDORN, C. MCCREADY, R. G. L. Urea transformation and fertilizer efficiency in soil. Advances in Agronomy, San Diego, v. 40, p. 209-238, 1986. http://dx.doi.org/10.1016/S0065-2113(08)602837

IPNI. 2014. International Plant Nutrition Institute (IPNI). Fertilizantes. Disponível em: http://brasil.ipni.net/article/brs-3132\#aparente. Acesso em 20 de outubro de 2015.

KISS, S.; SIMIHAIAN, M. Improving efficiency of urea fertilizers by inhibition of soil urease activity. Norwell: Kluwer Academic, 2002. 393 p. http://dx.doi.org/10.1007/978-94-017-1843-1

LADHA, J. K.; KUMAR, V. Direct seeding of rice: recent developments and future research needs. Advances in Agronomy, San Diego, v. 111, p. 297-396, 2011. http://dx.doi.org/10.1016/B978-0-12-387689-8.00001-1

LARA-CABEZAS, W. A. R. Manejo de gramíneas cultivadas em forma exclusiva e consorciada com Brachiaria ruziziensis e eficiência do nitrogênio aplicado em cobertura. Revista Brasileira de Milho e Sorgo, Sete Lagoas, v. 10, p. 130-145, 2011.

MALAVOLTA, E.; VITTI, G. C.; OLIVEIRA, S. A. Avaliação do estado nutricional das plantas: princípios e aplicações. 2.ed. Piracicaba: Potafos, 1997. 319p.

MORO, E.; CRUSCIOL, C. A. C.; CANTARELLA, H.; NASCENTE, A. S. Upland rice under no-tillage preceded by crops for soil cover and nitrogen fertilization. Revista Brasileira de Ciência do Solo, Viçosa, v. 37, p. 1669-1677, 2013.

NASCENTE, A. S.; CRUSCIOL, C. A. C. COBUCCI, T. Ammonium and nitrate in soil and upland rice yield as affected by cover crops and their desiccation time. Pesquisa Agropecuária Brasileira, Brasília, v. 47, p. 1699-1706, 2012. http://dx.doi.org/10.1590/S0100-204X2012001200004

NASCENTE, A. S.; CRUSCIOL, C. A. C.; COBUCCI, T. The no-tillage system and cover crops - alternatives to increase upland rice yields. European Journal of Agronomy, Amsterdam, v. 45, p. 124-131, 2013. http://dx.doi.org/10.1016/j.eja.2012.09.004

NASCENTE, A. S.; CRUSCIOL, C. A. C.; STONE, L. F. Straw degradation and nitrogen release from cover crops under no-tillage. Revista Caatinga, Mossoró, v. 27, p. 166-175, 2014.

PRANDO, A. M.; ZUCARELI, C.; FRONZA, V.; OLIVEIRA, F. A.; OLIVEIRA JÚNIOR, A. Productive characteristics of wheat according to nitrogen sources and doses. Pesquisa Agropecuária Tropical, Goiânia, v. 43, p. 34-41, 2013. http://dx.doi.org/10.1590/S1983-40632013000100009

PRANDO, A. M.; ZUCARELI, C.; FRONZA, V.; BASSOI, M. C.; OLIVEIRA, F. A. Forms of urea and nitrogen doses in top dressing in the agronomic performance of wheat genotypes. Semina: Ciências Agrárias, Londrina, v. 33, p. 621-632, 2012a. http://dx.doi.org/10.5433/1679-0359.2012v33n2p621 
PRANDO, A. M.; ZUCARELI, C.; FRONZA, V.; OLIVEIRA, E. A. P.; PANOFF, B. Forms of urea and nitrogen doses in topdressing on the physiological quality of wheat seeds. Revista Brasileira de Sementes, Londrina, v. 34, p. 272-279, 2012b. http://dx.doi.org/10.1590/S0101-31222012000200012

PRASAD, R. Aerobic rice systems. Advances in Agronomy, San Diego, v. 111, p. 207-236, 2011. http://dx.doi.org/10.1016/B978-0-12-387689-8.00003-5

SAS Institute. Procedure guide for personal computers. Version 5. Cary: SAS Institute Inc., 1999.

SILVA, A. A.; SILVA, T. S.; VASCONCELOS, A. C. P.; LANA, R. M. Q. Application of different sources of urea with gradual release in corn. Bioscience Journal, Uberlândia, v. 28, supl. 1, p. 104-111, 2012.

SOUSA, D. M. G.; LOBATO, E. Cerrado: correção do solo e adubação. Planaltina, DF: Embrapa Cerrados, 2003.

TRENKEL, M. E. Slow and controlled-release and stabilized fertilizers: An option for enhancing nutrient use efficiency in agriculture. Paris: International Fertilizer Industry Association, 2010. 123 p.

USDA, United States Department of Agriculture. 1999. Soil Taxonomy: a basic system of soil classification for making and interpreting soil surveys. 2nd ed. Washington: USDA. Disponível em:

bhttp://www.nrcs.usda.gov/Internet/FSE_DOCUMENTS/nrcs142p2_051232.pdfN. Acesso em: 15 de Novembro de 2015

VIANA, M. C. M.; FREIRE, F. M.; FERREIRA, J. J.; MACÊDO, G. A. R.; CANTARUTTI, R. B.; MASCARENHAS, M. H. T. Nitrogen fertilization on yield and chemical composition of signalgrass under rotational grazing. Revista Brasileira de Zootecnia, Viçosa, v. 40, p. 1497-1503, 2011.

WATSON, C. J.; POLAND, P.; ALLEN, M. B. D. The efficacy of repeated applications if the urease inhibitor $\mathrm{N}$-(n-butyl) thiophosporic triamide (nBTPT) for impruve the efficiency of urea fertiliser utilization on temperature grassland. Grass and Forage Science, Oxford, v. 53, p. 137-145, 1998.

http://dx.doi.org/10.1046/j.1365-2494.1998.5320137.x 